\title{
PROBLEMS IN THE ORGANIZATION OF THE SYSTEM FOR FINANCIAL MANAGEMENT AND CONTROL IN THE STATE RESERVE AND WAR-TIME STOCKS STATE AGENCY
}

\author{
Anton Marinov \\ Academy of the Ministry of Interior, \\ 1 Al. Malinov Blvd., 1715 Sofia, Bulgaria \\ antonmarinow@abv.bg
}

\begin{abstract}
Democratic changes have affected all aspects of life during recent years and have led to a reform in the way financial control is applied in the public sector in Bulgaria. The purpose of the current research paper is to analyze the system for financial management and control (SFMC) in the State Reserve (SR) and War-time Stock (WTS) State Agency and to pinpoint the problems that arise during the process of its functioning as well as to develop certain measures for its good financial management. The article reviews the essentials of the systems for financial management and control in the public sector as well as SFMC's structure, organization, and functioning at the SR WTS State Agency. The conducted research also presents various results and conclusions. The correctly functioning system of FMC provides reasonable confidence that the organization's aims are going to be accomplished by adhering to the principles of lawfulness, good financial management, and transparency.
\end{abstract}

Key words: financial management; financial control; public sector; Bulgaria

\section{ПРОБЛЕМИ ВО ОРГАНИЗАЦИЈАТА НА СИСТЕМОТ ЗА ФИНАНСИСКИ МЕНАҢМЕНТ И КОНТРОЛА ВО ДРЖАВНАТА АГЕНЦИЈА ЗА СТОКОВИ РЕЗЕРВИ И СТОКИ ВО УСЛОВИ НА ВОЈНА}

\begin{abstract}
Демократските промени имаат влијание во сите аспекти на животот во текот на последните години и доведуваат до реформи во начинот на кој се применува финансиската контрола во јавниот сектор во Бугарија. Целта на овој труд е да се анализира системот за финансиски менаџмент и контрола (SFMC) во Државните резерви (SR) и Државната агенција за военовременска берза (WTS) и да се посочат проблемите кои се јавуваат во процесот на нивно функционирање, како и да се развијат одредени мерки за негов добар финансиски менаџмент. Во трудот се разгледуваат основите на системите за финансиски менаџмент и контрола во јавниот сектор, како и структурата на SFMC, организацијата и функционирањето на SR и WTS. Спроведеното истражување презентира различни резултати и заклучоци. Правилното функционирање на системот на финансиски менаџмент и контрола обезбедува целите на организацијата да се остваруваат со почитување на принципите на законитост, добар финансиски менаџмент и транспарентност.
\end{abstract}

Клучни зборови: финансиски менаџмент; финансиска контрола; јавен сектор; Бугарија

\section{INTRODUCTION}

Democratic changes have affected all aspects of life during recent years and have led to a reform in the way financial control is applied to the public sector in Bulgaria. Conceptual, legislative and structural reforms of the financial control frame in the public sector were made before our joining the European Union, in order to increase the management responsibility of the organizations' leaders in this sector and the introduction of independent internal audit.

The purpose of the present research paper is to analyze the system for financial management and control (SFMC) in the State Reserve (SR) and War-time Stocks (WTS) State Agency and to identify the problems that arise in the process of its functioning, as well as to develop certain measures for improvement of its financial management. 
The object of the present research is the State Agency "State Reserve and War-time Stocks".

The subject of the research is functioning of SFMC in the State Agency "State Reserves and War-time Stocks".

In the process of research different methods of collecting and processing information have been used such as studying and analyzing documents, observation, analyses, comparison.

The correctly functioning system of FMC, which involves the principles of effectiveness, efficiency and economy, provides reasonable confidence that the risk of inappropriately timed, inadequate prevention, revelation and recovery of the damages is reduced to a minimum.

\section{THEORETICAL BACKGROUND}

The Financial Management and Control in the Public Sector Law (FMCPSL) [1] and the Internal Audit in the Public Sector Law (IAPSL) [2] were passed by the Parliament and came into effect in 2006. These laws regulate public relations, regarding the good management of public resources and protection of the financial interests of the country.

The Financial Management and Control in the Public Sector Law introduces the principle of management responsibility and demands the leader of an organization in the public sector to manage public resources in a lawful, economic, effective and efficient manner in order to achieve the aims of the organization and to guarantee that public interests will not be harmed in any way. The Internal Audit in the Public Sector Law regulates the essence, the scope and the organization of the decentralized model of internal audit in the public sector.

The principle of good financial management is transposed by the Regulation 1605/year 2002 [3] in the common budget of the European communities. It demands public resources to be spent and managed economically, effectively and efficiently. These categories are not new in Bulgarian law and practice, they are regulated in the National Audit Office Law and in the cancelled National Internal Financial Control Law.

FMCPSL regulates the range and the implementation of the financial management and control in the public sector, the principles and the requirements towards the systems of financial management and control. It is based on the interna- tional standards concerning professional practice in internal audit of The Institute of Internal Auditors Inc. and on the instructions related to the standards in the internal control in the public sector, introduced by INTOSAI (International organization of supreme audit institutions, which Bulgarian National Audit Office is a member of). It defines the basic components of the Enterprise Risk Management (ERM), it analyzes the basic principles and conceptions and submits clear instructions in the risk management on organizational level.

The Financial Management and Control in the Public Sector Law focuses on management responsibility, according to which control means not only financial control, but control of every aspect in the work of the organization. A new integrated framework comprehension about the internal control is adopted. It includes five elements, related to each other such as: control surroundings, risk management, control activities, information and communication and monitoring. In this comprehension the financial management and control is defined as a complete process, integrated in the work of the organizations and applied by its management and its staff [4]. The only way to achieve this is by creating and functioning the systems for financial management and control (SFMC). It includes policies, procedures and activities, meant to bring in reasonable confidence that the aims of the organizations will be achieved by:

- Conforming to law, internal acts and contracts;

- Reliability and universality of financial and operative information;

- Economy, effectiveness and efficiency of the activities;

- Preserving the assets and the information;

- Introduction of reasonable confidence in achieving the aims of the organization;

- Management responsibility and good financial management.

Risk management has a key role in choosing appropriate control activities - rules, procedures and activities, which give reasonable confidence that the risks in achieving the aims are reduced and limited to admissible boundaries set up in advance.

No matter how well-structured and managed the internal control is, it cannot give the management absolute confidence in achieving of the aims of the organization, so the term "reasonable confi- 
dence" was introduced. The possibility of failure in getting absolute confidence is limited by one of the following factors:

- The organization cannot envisage and manage all risks, threatening the achievement of its aims;

- Expenditure on internal control should not outweigh the expected benefit of its application.

The manager of the organization is responsible for the definition and the achievement of these aims by managing the risks and creating an adequate internal control in the following directions:

1. To ensure all members of the staff will abide the law including secondary legislative acts, internal acts and contracts, in which they are party.

2. Organization of registration, preservation, usage and submission of both financial and nonfinancial information by the organization. It is essential, being the ground on which tasks are completed, decisions are made, as well as the preparation of legitimate and accurate financial reports relies on it.

3 . The principle of good financial management is based on three requirements - economy, effectiveness and efficiency:

- Economy means the resources needed for organization's business that are obtained with least spending, fulfilling the requirements for quality, quantity and good timing.

- Effectiveness is a degree of achievement of the aims comparing the expected results with the real ones.

- Efficiency means reaching maximum results by the resources used in the process of work in the organization.

4. Gaining, using and managing assets and information demand special caretaking from the manager. The created internal control should guarantee the preservation of the assets and the information and to be preventive to theft, abuse, destruction and other illegal actions. The manager should pay special attention to the preservation of the assets and the information regarding the progress of information technologies and their implementation in the organization.

There is a strong relation between the aims of the organization (what the organization tries to achieve) and the elements of SFMC (what is necessary to achieve the aims).

In LFMCPS the elements of financial management and control - control surroundings, risk management, control activities, information and communication and monitoring are defined, as well as the responsibilities of the managers of the organizations for their creation, development and functioning.

1. Control surroundings sets the climate in the organization and impacts both managers' and staff's attitude towards financial management and control. This includes:

- Personal honesty and professional ethics, including compassion with the management and control at any time in the whole organization. Every single person in it (managers as well as staff) should continuously maintain and demonstrate both personal and professional honesty and ethical values. They should also report in cases of interest conflicts.

- Management philosophy and work style that support the theory that the manager should give good example to the staff by acting right, not acceptably or advisably.

- The organizational structure should delegate responsibilities and provide hierarchy and clear rules, rights, obligations and levels of reporting.

- Policies and practices in human resources management regarding staff recruitment, attestation, promotion, payment and training.

- Competence of the staff, including levels of knowledge and skills, needed to guarantee good, ethical, economical, effective and efficient implementation, as well as good understanding of personal responsibilities related to the financial management and control.

2. The second element - risk management is a process of identifying the risks, it estimates whether they fit in the acceptable limits or not. If not, appropriate measures are undertaken. It is meant to give reasonable confidence that the aims of the organization will be accomplished as well as to ensure correspondent management of the separate risks with the strategy and policy of the organization. Law demands managers of the organizations in the public sector to adopt three-year strategies for risk management, which can be updated if significant amendments occur in the risk surroundings.

3. The purpose of the control activities is to support the risk management, in order to assist the organization in achieving its aims. The effective system of financial management and control is supposed to guarantee that risks are limited in the acceptable boundaries, defined in the process of risk management. Extremely important for the control activities is to be adequate and expenses for them to be less than the expected benefits. Law 
regulates the implementation of the obligatory control activities as procedures of permission and approval, division of responsibilities, system of double signature, preliminary legal control, rules for access to assets and information. The manager of the organization and the person, responsible for accounting registers are those, whose signatures approve of financial obligations and payments. Preliminary control is implemented by financial controllers and other people, authorized by the manager.

4. The managers of the organizations are obliged to create and apply reliable information and communication systems. They should identify, collect and disseminate reliable and authentic information, including horizontal and vertical communication from one hierarchy level to the others and properly timed accounting system.

5. Monitoring system is the fifth element of the financial management and control. Its purpose is to estimate the degree of adequate functioning and to guarantee proper updating. The monitoring is being implemented by current observation, selfevaluation and internal audit. The procedure and means of implementation of the internal audit and reporting the results is regulated by a special law The Internal Audit in the Public Sector Law [2].

All elements are co-related, they complete each other and they apply not only to the whole organization but to its separate departments, activities and processes. The SFMC elements can be applied to every organization in the public sector overall.

The manager of the organization is the one, who should make the decision what kind of rules, procedures and activities should be introduced and how they should be updated in order to fulfill the requirements of the application of the elements of the SFMC law.

When there are separate structures in the organization's system, the superior manager is in duty of introducing these methodical directions to the inferior managers in order to apply them. The absence of additional directions does not relieve these structures' managers of the responsibility to develop and implement internal control.

\section{RESULTS AND DISCUSSION}

\author{
"State Reserve and War-Time Stocks" State \\ Agency's profile \\ "State Reserve and War-Time Stocks" State \\ Agency ("SR and WTS" SA) is a Ministerial
}

Council's body specialized in implementation of the state policy in the field of accumulation, preservation and usage of state reserves and state wartime stocks in correspondence with national security's interests. In the state reserve system the following basic stocks are stored - fuels; chemicals; food; ferrous and non-ferrous metals; spare parts; wood and paper; medicine; hospital and sanitary equipment, apparatuses and instruments.

The agency implements state supervision on creation, preservation, usage and refund of compulsory stocks of oil and oil products by the Compulsory Stocks of Oil and Oil Products Law [5].

The mission, the strategic aims and priority tasks of "SR and WTS" SA are defined in the State Reserve and War-time Stocks Law [6] and the aims of "State Reserve and War-time Stocks" State Agency for the year of 2011 [7].

The mission of the Agency is implementation of state policy in the field of planning, creating, preserving, saving, renewing, maintaining, releasing, accounting, financing and control of the state reserve and war-time stocks in correspondence with the interests of the national security.

The main strategic aim of "SR and WTS"SA is to maintain state reserve, war-time and crisis stocks in sorts and quantity sufficient to satisfy both national economy's and population's needs in time of crisis, in state of war, martial law or state of emergency.

The organization of the activities and the functional obligations of the administrative departments in the Agency are described in the main organizational document - Arrangement regulations of "SR and WTS"SA [9].

The powers and the management responsibility of the chairman, the deputy chairman, the secretary general and the other managing officials, as well as those of the staff, are in correspondence with the law in operation. They are represented in the functional characterizations of the officials in charge and the departments, described in the arrangement regulations, as well as in the occupational characterizations.

Vertical communication and subordination between different management levels and positions in the Agency are regulated in the arrangement regulations of the Agency; policy in implementation of the management responsibility; accounting procedures and accomplishment reporting; policy and procedures for information and communication; management's orders; conference and meeting protocols, announcements [9]. 


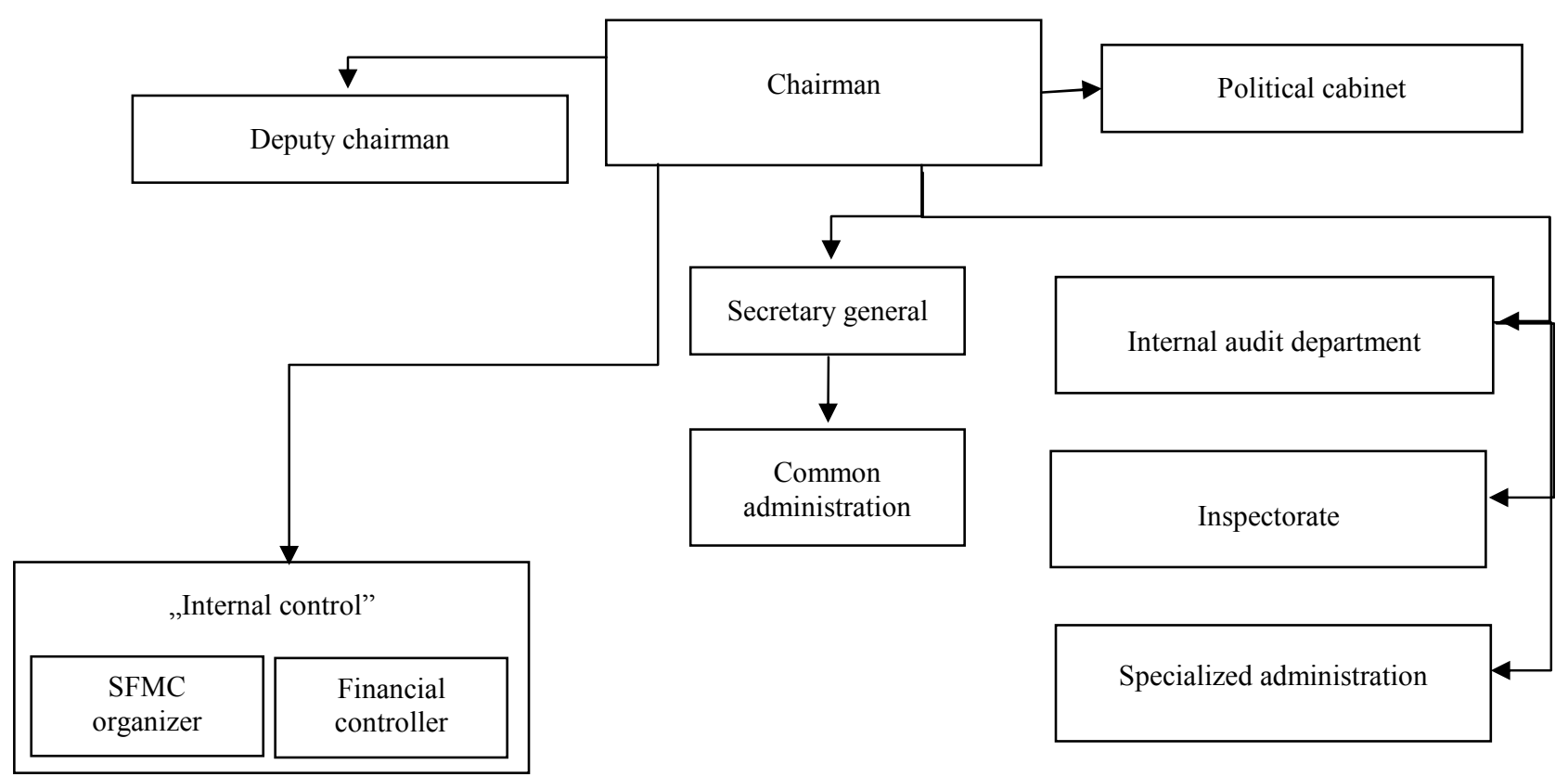

Fig. 1. Organizational structure of "SR and WTS" SA

The vertical communication and subordination are based on the principles - authorization of power and obligations "from top to low" and accounting and accomplishment reporting "from low to top"

Analysis of the system of financial management and control(SFMC) in "State Reserve and War-time Stocks" State Agency

The organization has good traditions and experience in the field of control even before the introduction of FMCPSL requirements, which are being currently applied to the organization, but when SFMC was formed they have been enriched, expanded and in correspondence with the new conditions and requirements such as: ratified rules and procedures in human resources management, accounting and documenting organization, preliminary control.

The introduction of SFMC aims to reach maximum level of effectiveness in risk management, management and control in the Agency, as well as giving reasonable confidence in achieving the aims by most effective usage of external and internal resources (administrative potential, equipment, informational and normative sources). The system is being introduced in "State Reserve and War-time Stocks" SA by stages. At every stage functions expand as well as the range of included policy, procedures and activities.

Fundamental and determinative factor of good financial management and control in the Agency is creating and maintaining a motivation both in employees and managers to achieve the aims by periodical and objective evaluation of their work (on the basis of clear and transparent rules and procedures), and fair payment for accomplished results.

SFMC of "SR and WTS"SA covers all activities, related to risk management, overall management and internal control. It is process-orientated and it is structured in five fundamental elements:

- Control surroundings;

- Risk evaluation and assessment;

- Control activities;

- Information and communication;

- Monitoring.

\section{Control surroundings}

The control surroundings in "SR and WTS" SA set the climate and impact both management's and staff's attitude towards the aims, the risk management processes, the management and control in the Agency. The control surroundings are basis for other SFMC elements and provide its structure and functioning. Control surroundings include:

Professional ethics and integrity, as an element of the control surroundings is represented in the "Ethical rules for employees' behavior in "SR and WTS" SA";

Management philosophy and style is represented in "Policy in implementation of management responsibility" and "Authorization of powers"; 
Organizational structure as powers, functional obligations and responsibilities is represented in "Arrangement regulations of "SR and WTS" SA" and as an organigram in "Organizational structure of "SR and WTS" SA";

The policy and practices in the field of human resources are represented in "Internal arrangement regulations of activity and organization of human resources management and organizational development in the administration of "SR and WTS" SA" and "Internal rules for human resources management".

The control surroundings are fundamental for all other components of internal control, providing structural order and staff discipline. They set the climate in the Agency and impact staff's attitude towards control.

\section{Risk evaluation and assessment}

Risk evaluation and assessment is an important component of SFMC in "SR and WTS" SA. It is developed as a process of identification and analysis of risks characteristic to the Agency's aims and defines appropriate reactions.

The elements of risk evaluation and assessment include:

- Identification of the risks:

- Considering Agency's aims;

- Considering the impact of the external and internal factors of the surroundings;

- Risk analysis:

- In terms of significance of each risk;

- In terms of probability to arise;

- Defining reaction to the risk:

In terms of different reactions- transferring, tolerating, decreasing, terminating.

In terms of choice of an appropriate mechanism for risk management- preventing and correcting.

Risk evaluation and assessment includes risk management and it is based on the Agency's risk management strategy and periodical checks of the departments and the Agency as a whole, in order to evaluate the degree of correspondence between the ongoing processes and the ratified (adopted) rules. Risk management strategy is developed on the basis of The Financial Management and Control in the Public Sector Law. The tasks of the risk management strategy in "State Reserve and Wartime Stocks" SA are:

1. To ratify certain approach of identification, evaluation and ways of reporting of the risks, threatening the achievement of "State Reserve and War-time Stocks" SA's aims.

2. To ratify a methodology for analysis and update of the control activities in order to reduce risks to acceptable levels.

3. Clear division of risk management responsibilities, including reports for their implementation.

4. To provide information to the employees in "State Reserve and War-time Stocks" SA for recently introduced risk management procedures.

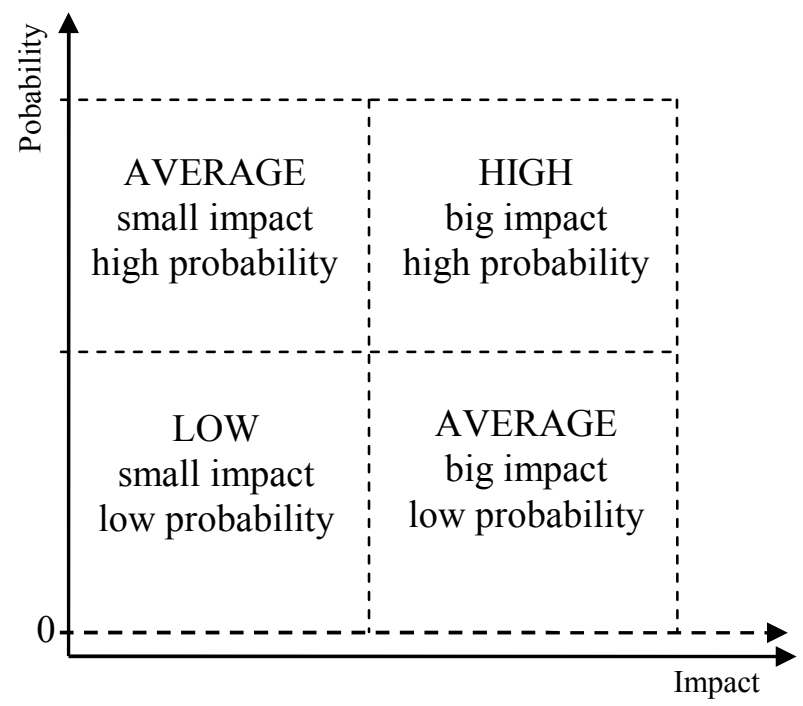

Fig. 2. Matrix for risk evaluation and assessment in "SR and WTS" SA

Risk management includes identifying, evaluation and control of potential events and situations, which may have negative effect on the achievement of the Agency's aims and it is meant to give reasonable confidence that they will be accomplished.

Identified risks are estimated by evaluating their degree due to internal criteria adopted by the organization. Evaluation of the identified risks is implemented by comparing the probability of their occurrence and the impact (effect) they might have:

Table 1

Risk categorization

\begin{tabular}{ll}
\hline \hline Importance of the risk & \\
\hline $\begin{array}{l}\text { High } \\
\text { (high degree of discrepancy) }\end{array}$ & $\begin{array}{l}\text { Under } 3.00 \\
\text { estimated points }\end{array}$ \\
Average & From 3.01 to 6.00 \\
(average degree of accordance): & estimated points \\
Low & More than 6.00 \\
(high degree of accordance): & estimated points \\
\hline \hline
\end{tabular}


On the basis of the matrix for correspondence assessment, risks are being evaluated in "State Reserve and War-time Stocks" SA and are being split in three categories:

High risk means that not all of the risks are covered with control procedures;
Medium risk means that all of the risks are covered with control procedures to a certain extent, but they are not effective enough;

Low risk means that all of the risks are covered with adequate control procedures, which are very effective, there are no or only a few insignificant deviations.

\section{Table 2}

Common risks, which have impact on the achievement of State Reserve and War-time Stocks" SA's aims

\begin{tabular}{|c|c|}
\hline \multicolumn{2}{|l|}{ External risks } \\
\hline Infrastructure & $\begin{array}{l}\text { Infrastructural problems, which hinder the normal functioning such as overloading the energy supplying or } \\
\text { informational systems, strikes, etc. }\end{array}$ \\
\hline Economics and market & $\begin{array}{l}\text { Modification of interest rates, impact of inflation processes, which may have a negative effect on the } \\
\text { activity of the Agency. }\end{array}$ \\
\hline Legislation & $\begin{array}{l}\text { Legislation modifications may cause changes in the range of the planned activities or restriction measures } \\
\text { may be enforced. }\end{array}$ \\
\hline Environment & Pollution, oil usage and others may have damaging effect on the environment in Agency areas. \\
\hline Politics & Political changes may cause changes in the aims of the Agency. \\
\hline Natural disasters & $\begin{array}{l}\text { Fires, floods and other natural disasters may have impact on the possibility of taking the actions needed. } \\
\text { The present strategy for natural disaster counteraction may prove inadequate. }\end{array}$ \\
\hline \multicolumn{2}{|l|}{ Financial risks } \\
\hline Budget & Lack of resources for undertaking the necessary actions and failure in their management and control. \\
\hline Frauds and thefts & Loss of assets, resources of disposal are not sufficient to provide the preventive actions wanted. \\
\hline Insurance & Risks out of insurance or at unacceptable cost of insurance. \\
\hline Investments & Inappropriate investment decisions. \\
\hline Financial obligations & "State Reserve and War-time Stock" SA's responsibility for damages to third parties. \\
\hline \multicolumn{2}{|l|}{ Activity risks } \\
\hline Policy & Inappropriate policy; policy, based on inadequate or inaccurate information. \\
\hline Operative & Aims too high for the organization. Fulfillment not correspondent to the aims. \\
\hline Information & Inaccurate information may lead to taking inappropriate management decisions. \\
\hline Reputation & Bad reputation and its consequences. \\
\hline Technological & Technological issues during the implementation of the activities. \\
\hline Projects & Implementation of projects without proper risk assessment. Failed projects due to poorly timed finance. \\
\hline Innovations & Not using opportunities for innovations. Introduction of new approaches without proper risk management. \\
\hline \multicolumn{2}{|l|}{ Human resources } \\
\hline Competence, ethics & Lack of qualified employees, disrespect of the acknowledged ethical norms of behavior (Ethical code). \\
\hline $\begin{array}{l}\text { Healthy and safe work } \\
\text { conditions }\end{array}$ & Not providing healthy and safe work conditions. \\
\hline
\end{tabular}

Identification of risks in "State Reserve and War-time Stocks" SA is implemented by:

1. Actual checks in the agency;

2. Records check-ups;
3. Observation;

4. Reports;

5. Written statements;

6. Questionnaires; 
7. Interviews;

8. Inquiries;

9. Other methods, approved by the management.

Risk management in "State Reserve and Wartime Stocks" SA is implemented by:

1. Definition and categorization of the risks, which threaten the achievement of the aims;

2. Introducing risk control activities, which reduce risks to levels, approved by the management as acceptable;

3. Monitoring and periodical reassessment of the existing risks;

4. Preparing reports for the management, which provide information about stated problems with a view to taking actions to eliminate them;

5. Undertaking correction activities on the basis of monitoring information and filing in reports with the results of their application.

The manager of the organization introduces system of internal reporting about identified risks, complying with the requirements for being timely, periodical and explicit. This system should guarantee that structural departments in the organization periodically report about noticed risks and activities undertaken as a reaction to the risk

\section{Control activities}

The control activities are basic component of SFMC in "SR and WTS" SA. They are developed on the basis of the requirements of FMCPSL and internal regulatory acts of the Agency. They are meant to introduce control mechanisms for risky areas by the financial management and control and overall management of the Agency.

The control activities include written procedures and activities, related to:

- Permission, approval and authorization;

- Delegation of responsibilities;

- Double-signature system;

- Preliminary control;

- Complete, accurate and authentic accounting of all operations;

- Observation;

- Review of activities and operations;

- Anticorruption procedures;

- Rules for access to assets and information;

- Rules in human resources management;
- Documentation, archiving and preservation of the information.

\section{Information and communication}

The information and the communication are specific components of SFMC in "SR and WTS" SA. They are necessary on all levels in the Agency, in order to define, estimate and respond to the risk. Information and communication can create opportunity for proper risk evaluation, ethics, economy, effectiveness and efficiency of the activities.

The information is necessary in order effective internal control to be implemented and aims to be achieved. The information provided should be: properly timed, adequate, up-to-date, accurate, authentic and in simple form. The communication should be transparently regulated.

Effective communication should run both on the vertical and the horizontal communication channels of the Agency, throughout all components in the structure. One of the most important channels is the one between the management and the staff.

\section{Monitoring}

Monitoring is mostly implemented as a current activity and it is responsibility of the management. It is an overall review of the Agency activity, which aims to give confidence that the introduced control activities function in their directions and remain effective in time.

Monitoring is implemented by current observations of SFMC, organized during the very functioning, by recording in operative documents concerning different procedures and special reviews (evaluations), which are performed in procedures for risk estimate and operative control.

Monitoring of all significant risks should be reported to the manager of the organization.

\section{Documentation of the system of financial management and control in "SR and WTS" SA}

The documentation of SFMC includes the following hierarchic levels:

- First level: SFMC guide

- Second level: Basic procedures and working instructions

- Third level: Operative documents and records

SFMC guide is the most fundamental and summarized document it the System of financial 
management and control in which the Agency management announces its policy and aims in financial management and control, organizational structure, management policy and practices, needed to achieve the set aims. With the rest of the documents (procedures, working instructions and operative documents) details are worked out in the System of financial management and control.

The procedures in financial management and control contain detailed description of processes, which are included in SFMC in "State Reserve and War-time Stocks" SA, as well as the responsibilities, competences and organizational relations between the structural departments and the officials in correspondence with the fulfillment of the requirements. The procedures in SFMC refer to working instructions, control instructions, arrangement regulations, rules and documents of the Agency.

Working instructions describe particular activities, stages of processes and add details to the requirements of good financial management and control and procedures in risk management, supervision and control.

Operative documents in SFMC are used as records in quality after their filing.

The documents of SFMC cannot be contradictory to state regulatory and administrative orders, as well as to introduce and ratify internal rules of the Agency.

Besides the mentioned document categories, SFMC includes other documents of internal and external origin.

To the documents of internal origin are assigned all internal-regulatory documents, issued by the management authorities in "State Reserve and War-time Stocks" SA such as arrangement regulations, instructions, decisions, orders, internal rules, statutes, strategies, conceptions, programs etc.

To the documents of external origin are assigned all kinds of current regulatory documents of the law in operation in the country, the standards and all other documents of external origin, which have impact on the regular activity of the Agency.

Up-to-date versions of the SFMC documents are kept by the SFMC organizer.

For document and records management in SFMC there is a procedure "Document and records management in SFMC", in which the sequence of composition, verification, approval, recognition, identification, multiplication, distribu- tion, control, modification, protection of illegal usage of expired documents, conservation (backup) and destruction of all documents in SFMC, used in "State Reserve and War-time Stocks" SA, as well as the management of documents of external origin are regulated.

\section{Functions and tasks to the management of} "SR and WTS" SA according to SFMC

The main functions of the management of "SR and WTS" SA according to SFMC are:

- Preparation and introduction of SFMC procedures;

- Implementation of periodical internal reviews of SFMC functioning;

- Production and permanent actualization of SFMC documents;

- Development of procedures and instruments for collecting objective data about the quality of the SFMC functioning;

- Production and permanent actualization of SFMC internal-regulatory basis in financial management and control;

- Theme check-ups (reviews) based on Management's decision and related to problematic departments and activities;

- Introduction of up-to-date data and usage of informational system in SFMC corresponding to the recognized hierarchy system of access to it;

- Support of the analysis, conclusions, forming of the management activities and monitoring the effect of management's impact on SFMC improvement;

- Reporting the results of the activities.

The management of "State Reserve and Wartime Stocks" SA makes review and evaluation of the state, adequacy and effectiveness of SFMC at least once a year. On the basis of the results possible modifications are made, including changes of policy and aims of the financial management and control.

SFMC's organizer makes and introduces Report on the state of the System for financial management and control, which should contain the following basic elements:

- Results of the risk assessment check-ups implemented during the past year;

- Feedback from the employees and citizens about the problems in processes and activities, regulated by SFMC;

- Information about the functioning of the processes in financial management and control, as 
well as correspondence between internal and external regulatory requirements;

- State and effectiveness of preventing and correcting activities in SFMC;

- Degree of implementation of the recommendations from previous management reviews;

- Suggestions for changes, which can improve the effectiveness of SFMC;

- Other information, concerning adequacy and effectiveness of SFMC.

In order effective maintenance of SFMC to be defined and in correspondence with the requirements of the legislation and internal regulatory basis, in "State Reserve and War-time Stocks" SA periodical internal reviews are made in correspondence with "Review and evaluation of the SFMC". The organizer in SFMC is responsible for the overall organization and the implementation of internal reviews.
Internal reviews are implemented by employees in the Agency under the management and methodical cooperation of the SFMC Organizer. If there are faults, discovered during the internal reviews, corresponding corrections should be undertaken due to the procedure "Correcting activities".

In the process of internal reviews of SFMC different aspects of the activities and operations in the departments and structures of the Agency are observed and estimated and on the basis of the collected information analysis of the effectiveness of the observed processes is implemented and if it is necessary, preventive or correcting activities are undertaken.

The system for evaluation of SFMC is based on the closed control outline with feedback, in which "obtained" is compared to "planned".

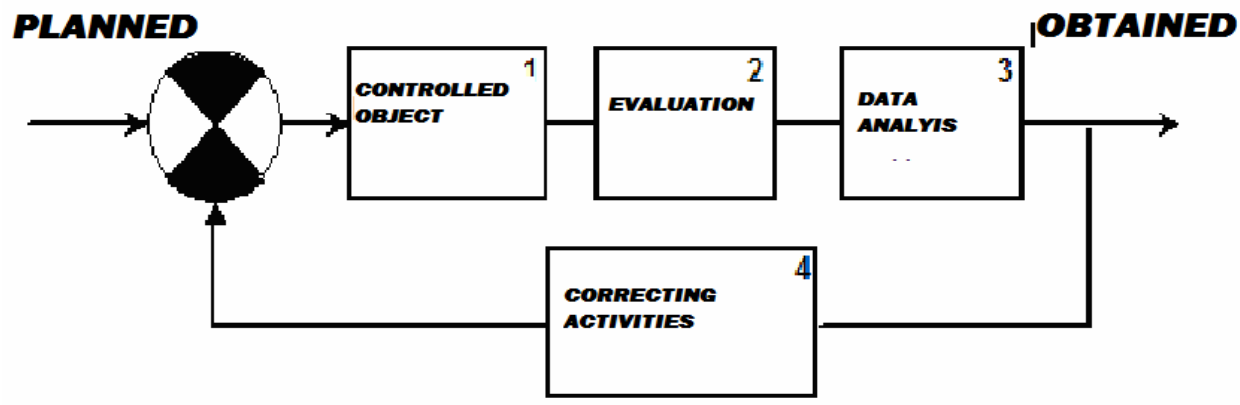

Fig. 3. Scheme of the system for evaluation the quality of training

Aims and tasks assigned to the system of financial management and control can be on level function, activity, department and employee.

The evaluation of their achievement is implemented on the basis of regular inquiry researches, observations, private researches, made by the SFMC organizer. Results and primary analysis are presented to the proper managers for following detailed analysis, and if it is necessary, preventive or correcting activities to be undertaken.

In this way a cycle for permanent improvement is created and functions in order to meet the requirements for adequacy and effectiveness of SFMC, in correspondence with the aims of the Agency.

All managers and employees in "State Reserve and War-time Stocks" SA, who are engaged to the functioning of SFMC, are obligated in the restrictions of their responsibilities and competence to undertake actions for elimination the causes for any obvious discrepancy or other unwelcome or potentially dangerous situation, which has impact on the requirements for SFMC and the quality of the Agency activity. Actions are being implemented by defining means of:

- Identifying the reasons, which can cause potential discrepancies, as well as hypothetic evaluation of the overall influence of the problem;

- Defining and providing application of the necessary preventive action;

- Identifying discrepancy by means of results of internal audits, internal reviews, information from the employees and complaints from the citizens; 


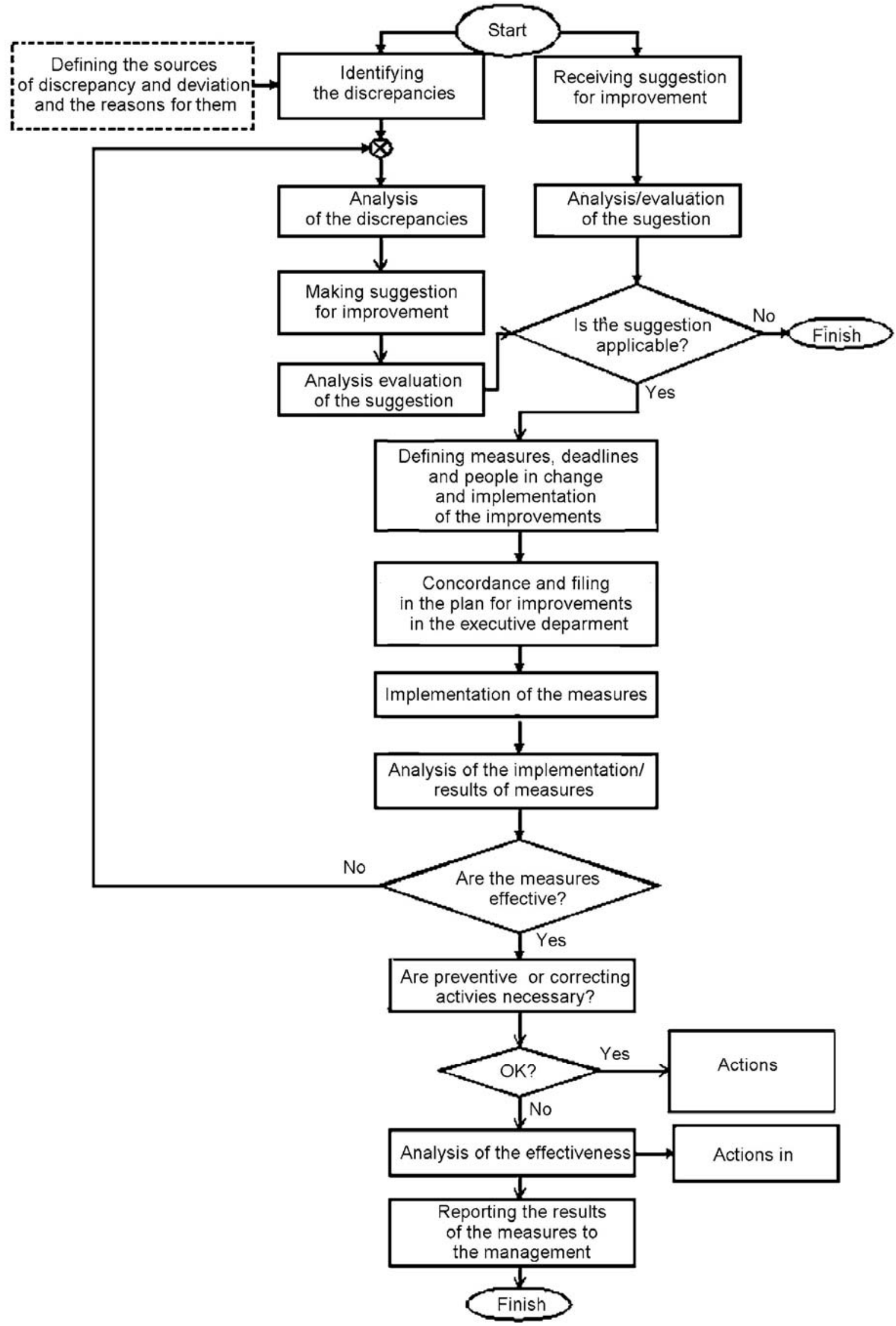

Fig. 4. Description of the process of measures for improvement 


\section{Measures for improvement of the system in financial management and control in "SR and WTS" SA}

After analyzing the system of financial management and control in "SR and WTS" SA the following measures for its improvement could be offered:

1. Control activities should be appropriate, to function in correspondence with the planned in the current period, to be effective regarding expenditures, to be complete, reasonable and related to the common aims of the organization. When introducing the control activities, the manager should consider the benefit expected from them, as well as the spending on their introduction and implementation. Control activities should be introduced in the processes and the systems at the moment of their construction. Following introduction of control activities would be more expensive and less effective.

2. Strict respect of the introduced measures for improvement. By this regulation the discovered discrepancies and new suggestions are used for improving the processes of risk management, supervision and control. The implemented improvements should be regulated in the future process approach in order relapses of discrepancies to be eliminated. The procedure should be applied to all departments and by every person in "State Reserve and War-time Stocks" SA, related to the system of financial management and control.

\section{CONCLUSION}

Financial management and control in the public sector is a specific activity, which is implemented in order to provide achievement of the defined aims of an organization, functioning in the system of public sector.

The legislator has accepted that the financial management and control in the public sector is a complete process, included in the work of the organizations which are given specific function implemented by both their management and staff. Practically, this work is put into effect by the corresponding systems, including policy and practices for the achievement of the aims, which every organization of the public sector confronts.

Absolute responsibility is introduced to those, who have state financial and material resources entrusted.

The system of financial management and control in "SR and WTS" SA (State Reserve and Wartime Stocks State Agency) is well constructed and can be pointed out as an example of good practice. This system is well functioning with positive results.

After the analysis made, the conclusion is that the system is firmly constructed, functions properly and gives good results. The measures shown are rather of a desirable and recommending character in order the system to be improved and completed. The latter may be introduced in other similar organizations in the public sector as an example of good practice.

Systems of financial management and control should be observed in order to guarantee that control mechanisms function in correspondence with the requirements and should be updated in a proper way if conditions change.

\section{REFERENCES}

1] Official Gazette, Issue 21 (2006): Financial Management and Control in the Public Sector Law - with modification and supplement.

2] Official Gazette, Issue 27 (2006): Internal Audit in the Public Sector Law - with modification and supplement.

[3] Regulation N 1605/2002 June $25^{\text {th }}$ (2002), regarding Financial Regulations, applicable to the common budget of EC.

[4] Official Gazette Issue 21(2006): Article 5 of the Financial Management and Control in the Public Sector Law (FMCPSL), with modification and supplement.

[5] Compulsory Stocks of Oil and Oil Products Law - Official Gazette, Issue 9, year 2003, with modification and supplement.

[6] State Reserve and War-time Stocks Law - Official Gazette, issue 9, year 2003, with modification and supplement.

[7] Aims of "State Reserve and War-time Stocks" State Agency for the year of 2011.

[8] Arrangement regulations of "SR and WTS" SA, took effect on 30. 01. 2004, with modification and supplement.

[9] www.statereserve.bg - Web site of the State Agency "State Reserve and War-time Stocks". the State Agency "State Reserve and War-time Stocks". 